\section{Transmission of Phosphorus-32 incor- porated by Parents into Descendants of Drosophila melanogaster}

The quantity and distribution in various phosphorus fractions of phosphorus-32 incorporated into parents by feeding on media containing phosphorus32 was followed in descendents of Drosophila melanogaster strain Algeria. The animals were bred at $25^{\circ} \mathrm{C}$, in incubators on Belgowsky's culture medium ${ }^{1}$ with some drops of a yeast suspension. Reciprocal crosses were made between animals grown on media containing isotopic and normal phosphorus. Repeated passages were carried out in order to eliminate the eventual contamination by phosphorus-32 of the culture media of the descended larvæ by the labelled parents. The fractionation of the phosphorus compounds was carried out according to the Schmit-Tannhauser method ${ }^{2}$. The amount of acid-labile phosphorus in the acidsoluble fraction was assayed by the method of Berenblum ${ }^{3}$. The lipoid-soluble fraction was extracted with a mixture of alcohol/other (3:1). Deoxyribonucleic acid (DNA) was separated after acidification with trichloracetic acid. The protein phosphorus, represented as orthophosphate, was separated from the DNA remaining in the solution by direct phosphorus determination.

The distribution in seven different fractions of phosphorus originating from the culture medium and transmitted to the progeny is shown in Table 1.

Table 1. Phosphorus Fractions in the Ontogeny of Drosophila

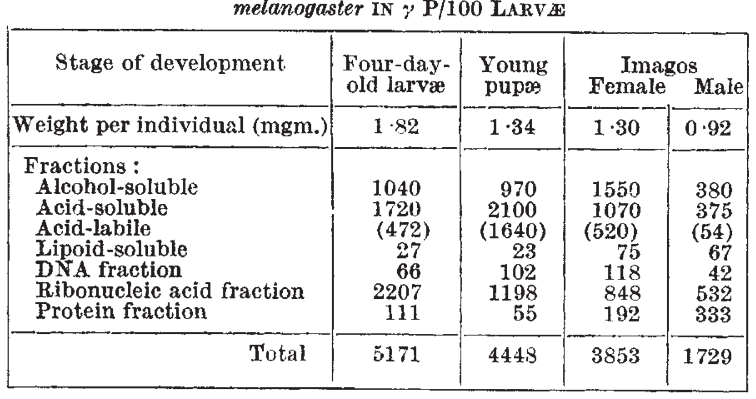

It may be seen that the intensive morphogenetical processes are preceded by a marked increase in the acid-soluble fraction, mainly at the expense of the alcohol-soluble one. From the pupal stage onwards an increase of lipoid phosphorus was observed. The lowering of ribonucleic acid (RNA) content is significant and might be responsible for the decreasing rate of protein synthesis. A pronounced increase in protein phosphorus was observed in the imago.

Table 2. The Distributron of Phosphords originating from Femalf and Malf gametes In the Phosphords Fractions of the

\begin{tabular}{|c|c|c|}
\hline Fractions & $\begin{array}{l}\text { Labelled female } \\
\times \text { normal male }\end{array}$ & $\begin{array}{l}\text { Normal female } \\
\text { labelled male }\end{array}$ \\
\hline $\begin{array}{l}\text { Alcohol-soluble } \\
\text { Acid-soluble } \\
\text { Acid-lablle } \\
\text { Lipoid-soluble } \\
\text { DNA fraction } \\
\text { RNA fraction } \\
\text { Protein fraction }\end{array}$ & $\begin{array}{l}4 \cdot 8 \\
8 \cdot 3 \\
(7 \cdot 4) \\
1 \cdot 5 \\
1 \cdot 3 \\
6 \cdot 2 \\
3 \cdot 3\end{array}$ & $\begin{array}{l}\text { traces } \\
0 \cdot 130 \\
\text { (traces) } \\
0 \cdot 042 \\
0 \cdot 054 \\
0 \cdot 099 \\
0 \cdot 150\end{array}$ \\
\hline Total & $25 \cdot 4$ & 0.475 \\
\hline
\end{tabular}

Table 3. THE DISTRIBUTION OF PhOSPHORUS DERIVED FROM THE MEDIUM AND FROM THE GAMETES IN THE $F_{1}$ LARVAE OF Drosophila (per cent)

\begin{tabular}{|c|c|c|c|}
\hline Fractions & $\begin{array}{c}\text { Culture } \\
\text { (pedium } \\
\text { (per cent) }\end{array}$ & $\begin{array}{l}\text { Labelled } \\
\text { female } \\
\text { gametes } \\
\text { (per cent) }\end{array}$ & $\begin{array}{c}\text { Labelled } \\
\text { male } \\
\text { gametes } \\
\text { (per cent) }\end{array}$ \\
\hline $\begin{array}{l}\text { Alcohol soluble } \\
\text { Acid soluble } \\
\text { Acid labile } \\
\text { Lipoid soluble } \\
\text { DNA fraction } \\
\text { RNA fraction } \\
\text { Protein fraction }\end{array}$ & $\begin{array}{l}20 \cdot 2 \\
33 \cdot 4 \\
(9 \cdot 1) \\
0 \cdot 7 \\
1 \cdot 3 \\
42 \cdot 2 \\
2 \cdot 2\end{array}$ & $\begin{array}{c}18 \cdot 8 \\
32 \cdot 9 \\
(29 \cdot 4) \\
5 \cdot 9 \\
5 \cdot 1 \\
24 \cdot 5 \\
12 \cdot 8\end{array}$ & $\begin{array}{r}27 \cdot 1 \\
(?) \\
8 \cdot 7 \\
11 \cdot 8 \\
20 \cdot 8 \\
31 \cdot 6\end{array}$ \\
\hline Total & $100 \cdot 0$ & $100 \cdot 0$ & $100 \cdot 0$ \\
\hline
\end{tabular}

The distribution of phosphorus-32 in the phosphorus fractions of the larvæ orginating from reciprocal crosses is given in Table 2.

It is clear that the quantity of phosphorus transmitted via the ovocyte is fifty times higher than that transmitted by the male gametes. This figure is probably even higher. We must take into consideration the possibility of polyspermy which is a widespread phenomenon in Drosophila melanogaster. In the case of a 25-fold polyspermy the transmission by ovocytes surpasses the male transmission 1,250 times. The possibility that the differences are to be attributed to a higher turnover rate of the ovocytes was eliminated by autoradiographic examinations.

The distribution of phosphorus-32 in the phosphorus fractions derived from the medium, from the gametes or the food is shown in Table 3 .

It can be seen that the distribution of phosphorus32 in various phosphorus fractions derived from food, from male or female gametes, is very different. It is obvious that an equal amount of labelled phosphorus is incorporated into the acid-soluble compounds of the alcohol-soluble fraction from both the food and the ovocytes. By contrast, only traces of a similar incorporation were found if the transmission took place via the male germ-cells. There was no remarkable difference in the acid-soluble fraction; however, more phosphorus was incorporated into the acid-labile fraction via the ovocytes than from the food. Relatively less phosphorus was recovered in DNA if incorporated directly from the food $t_{1}$ an after transmission via the gametes. The differences between the phosphorus content of the RNA and protein fractions might be explained by the different amounts of reserve substances and cytoplasm contained by the ovocytes.

\section{B. Faludi \\ I. Csukás \\ K. STZf́PLAKY \\ F. Á. DánIeI}

Department of Phylogenetics and Genetics, Eötvös Loránd University, Budapest.

${ }^{1}$ Bridges, C. B., Tabulate Biol., 14, 343 (1937).

2 Hoppe-Seyler-Thierfelder, Handbuch der Physiologisch- und Pathologisch-Chemischen Analyse (Zehnte Aufl. Berlin, 1955).

${ }^{3}$ Berenblum, I., and Chain, E., Biochem. J., 32, 295 (1930).

\section{Hexaploid Dactylis}

A RECEnT intensive survey of Dactylis has shown that tetraploids $(2 n=28)$ are widely distributed throughout the temperate parts of the world ${ }^{1}$. In Europe and Asia, regions where this genus is native, diploids are also found, and each of these has a comparatively limited range of distribution ${ }^{2}$. 